\title{
Communication
}

[Comunicação]

\section{Lymphocyte proliferative responses in dairy cows supplemented with an immunomodulatory feed additive and administered polyvalent vaccination}

\author{
[Proliferação de linfócitos em vacas leiteiras suplementadas com um aditivo alimentar \\ imunomodulador e vacinadas com vacina polivalente]
F.N. Souza ${ }^{1,2}$, T. Leiva ${ }^{3}$, R.O. Rodrigues ${ }^{3}$, J.R. Gandin Júnior ${ }^{3}$, E. Drago ${ }^{3}$, R.C. Gomes ${ }^{1}$, K.R. Santos ${ }^{1}$, M.G. Blagitz, ${ }^{1}$, A.M.M.P. Della Libera ${ }^{1}$, \\ J.L.M. Vasconcelos ${ }^{3}$, M.B. Heinemann ${ }^{1}$
}

\begin{abstract}
${ }^{1}$ Faculdade de Medicina Veterinária e Zootecnia - Universidade de São Paulo - São Paulo, SP ${ }^{2}$ Programa de Pós-Graduação em Ciência Animal - Universidade Federal da Paraíba - Areia, PB ${ }^{3}$ Faculdade de Medicina Veterinária e Zootecnia - Universidade Estadual Paulista - Botucatu, SP
\end{abstract}

The dairy cow's diet exerts a profound impact on immune function and consequently on its natural ability to resist infections. Thus, if the use of a dietary immunostimulant can enable the host to boost their immunity, it may have effects beyond the health of the individual cow, as it will minimize the undesirable use of antimicrobials, impacting public health and milk chain profitability.

OmniGen-AF ${ }^{\circledR}$ is a commercially available, patented, proprietary, branded feed additive that exerts immunomodulatory effects in nonruminant (Branson et al., 2016) and ruminant species (Wang et al., 2009; Nace et al., 2014; Brandão et al., 2016). Therefore, there are many gaps in the understanding of how this feed additive acts on the immune system. In addition, the majority of studies of this additive have focused on investigating its effect on the innate immune response, and its effect on the adaptive immune response is largely unknown. Nonetheless, we hypothesized that its implications are far-reaching and that it may also impact adaptive immunity functions, such as lymphocyte proliferation.

Our hypothesis is supported by some previous findings in murine models (Branson et al., 2016) and ruminants (Wang et al., 2009). For instance, this feed additive has the ability to modulate the production of interleukin (IL)-1 $\beta$ (Wang et al.,
2009), a pro-inflammatory cytokine, which affords an important linkage between innate and adaptive immune responses by providing an activating signal for lymphocyte proliferation (Murphy and Weaver, 2008). Indeed, our hypothesis was strengthened by the finding of increased expression of genes involved in cellmediated adaptive immune response, such as the induction of CD1D1 and CD80 antigen presenting receptors, and a trend toward up-regulation of CD86, which in turn may activate naïve $\mathrm{T}$ cells, resulting in the stimulation of responsive $B$ cells to proliferate and differentiate into plasma cells (Branson et al., 2016). To further investigate this scenario, the present study aimed to evaluate the effect of dietary OmniGen-AF ${ }^{\circledR}$ supplementation on lymphocyte proliferation in dairy cows under vaccination.

This study was conducted in February and March 2016 at the São Paulo State University Lageado Experimental Station located in Botucatu, São Paulo State, Brazil. This research complied with the Ethical Principles in Animal Research and was approved by the São Paulo State University Animal Bioethics Committee (Protocol n. 0201/2016).

Here, we used thirty-two lactating primiparous $(n=16)$ and multiparous $(n=16)$ Holstein $x$ Gir dairy cows. Samples from all dairy cows, which were not exposed to heat stress conditions, were 
collected for the leptospiral microscopic agglutination test, and samples from sixteen dairy cows (eight control and eight OmniGen- $\mathrm{AF}^{\circledR}{ }_{-}$ treated cows) were collected for lymphocyte proliferation. On day -6 , cows were uniformly divided based on parity, days in milk, body weight and body condition score to receive or not receive OmniGen-AF ${ }^{\circledR}$ (Phibro Animal Health, Teaneck, NJ, USA) at 56g/cow, daily as-fed basis, from day 1 to day 56, as previously detailed by Leiva $e t$ al. (2017). Then, dairy cows were vaccinated on days 56 and 70 with a commercial polyvalent vaccine (Cattle Master ${ }^{\circledR}$ 4+VL5; Zoetis, Kalamazzo, MI, USA) comprising chemically altered strains of infectious bovine rhinotracheitis virus and parainfluenza type 3 virus, modified live bovine respiratory syncytial virus, inactivated cytopathic and noncytopathic bovine viral diarrhea type 1 virus strains, and bacterins from Campylobacter fetus and strains of Leptospira interrogans serovar canicola, Leptospira kirschnerii serovargrippotyphosa, Leptospira borgpetersenii serovar hardjo, Leptospira interrogans icterohaemorrhagiae and Leptospira interrogans serovar Pomona.

On days 56 (immediately before vaccination) and 77 (21 days after prime vaccination), blood samples of approximately $20 \mathrm{~mL}$ from each cow were aseptically collected from the coccygeal vein and harvested into tubes without anticoagulant to obtain serum after centrifugation at $400 \mathrm{x} g$ for 15 min for the leptospiral microscopic agglutination test. At these times, blood samples were also harvested into tubes containing sodium heparin for lymphocyte proliferation tests.

The leptospiral microscopic agglutination test included 22 Leptospira sp. serovars (Australis, Bratislava, guaricura, Autumnalis, Butembo, Castellonis, Bataviae, Canicola, Whitcombi, Cynopteri, grippotyphosa, Hebdomadis, Copenhageni, Icterohaemorrhagiae, Javanica, Panama, Pomona, Pyrogenes, Hardjohardjoprajitno, Shermani, Tarassovi, Sentot) representing 18 serogroups. Endpoint titers were determined by starting at an initial dilution of 1:100 and using two-fold dilutions until a well showed $50 \%$ agglutination; this final value was recorded. The cutoff for a positive agglutination reaction was defined as a titer $\geq 100$ (Cole et al., 1973).
For lymphocyte proliferation, peripheral blood mononuclear cells (PBMCs) were isolated from each animal using Ficoll-Paque ${ }^{\mathrm{TM}}$ Plus $^{\circledR}$ (GE Healthcare, Piscataway, NJ, USA, cat. n. 171440-03, density gradient $1.077 \mathrm{~g} \mathrm{~mL}^{-1}$ ) following the manufacturer's instructions. The PBMCs were then placed in $1 \mathrm{ml}$ of the proliferation medium composed of RPMI-1640 nutrition media (cat. n. R7638, Sigma Aldrich, St. Louis, MO, USA) supplemented with $10 \%$ heat-inactivated fetal bovine serum (FBS; cat. n. F9665, Sigma Aldrich, St. Louis, MO, USA), 5 x $10^{-2} \mathrm{mM} 2-$ mercaptoethanol (cat. n. 21985-023, Invitrogen, Grand Island, NY, USA), $2 \mathrm{mM}$ L-glutamine (cat. n. 21051-024, GIBCO ${ }^{\mathrm{TM}}$ Invitrogen, Grand Island, NY, USA) and $100 \mathrm{X}$ antibioticantimycotic solution (cat. n. 15240-062, Life Technologies, Paisley, UK). Subsequently, trypan blue exclusion (cat. n. T8154-100ML, Sigma Aldrich, St. Louis, MO, USA) was used to determine the cell viability, which was always determined to be $>98 \%$; then, the PBMCs were counted in a Neubauer chamber, and their concentration was adjusted to $2.2 \times 10^{6}$ viable cells $\mathrm{mL}^{-1}$.

Lymphocyte proliferation was performed as described by Souza et al. (2011) using 5-(6-) carboxyfluorescein diacetate succinimidyl ester (CFSE; 5mM mL ${ }^{-1}$; cat. n. C1157, Invitrogen, Carlsbad, NY, USA) as a probe. Phytohemagglutinin M-form (PHA-M) and concanavalin-A type III (Con-A) were used for mitogen-induced proliferation of $\mathrm{T}$ lymphocytes (Soder and Holder, 1999), and lipopolysaccharides (LPS) from Escherichia coli 0127:B8 were used to induce the proliferation of B cells (Mehrzad and Zhao, 2008) at both 56 and 77 days. Thus, triplicate sets of samples were stimulated with $10 \mu \mathrm{L}$ of Con-A (at a final concentration of $10 \mu \mathrm{g} \mathrm{mL}^{-1}$; cat. n. C2631, Sigma Aldrich, St. Louis, MO, USA), LPS from E. coli O127:B8 (at a final concentration of $25 \mu \mathrm{g} \mathrm{mL} \mathrm{m}^{-1}$; cat. n. L3129, Sigma Aldrich, St. Louis, MO, USA), or PHA-M (10 $\mu \mathrm{L} /$ well; cat. n. 10576015 , GIBCO $^{\mathrm{TM}}$, Carlsbad, NY, USA).

A triplicate set of wells containing only $100 \mu \mathrm{L}$ of cells in proliferation medium served as controls. On day 77, heat-killed Leptospira borgpetersenii serovar hardjo at a multiplicity of infection (MOI) of 100 (100 leptospires per PBMC) was also used to induce lymphocyte proliferation, as animals had been vaccinated 21 and 7 days earlier with a 
polyvalent vaccine containing bacterins from different Leptospira serovar strains, including Leptospira borgpetersenii serovar hardjo. On the lymphocyte proliferation assay on day 77 , after the incubation, the B cells were identified using mouse anti-bovine CD21 conjugated with Rphycoerythrin (R-PE; cat. n. MCA1424PE, AbD Serotec, Oxford, England).

First, for flow cytometry analysis, the viable cells were gated according to their side- (SSC-H) and forward scatter (FSC-H) characteristics. Then, lymphocyte proliferation was determined by serially halving the fluorescence intensity of CFSE in total PBMCs and gated CD21 $1^{+}$cells (B cells at $77 \mathrm{~d}$ ). An unstained control and singlestained samples (CFSE or R-PE CD21) were also prepared as compensation controls. The sample readings were performed using a FACSCalibur ${ }^{\mathrm{TM}}$ flow cytometer (Becton Dickinson Immunocytometry Systems ${ }^{\mathrm{TM}}$, San Diego, CA, USA) with argon (488nm excitation) and diode (635nm excitation) lasers. For this assay, 50,000 ungated cells were examined in each sample. FlowJo Tree Star Software (FlowJo - Treestar 7.6.5 for Windows, Tree Star Inc., Ashland, OR, USA) was used to analyze the data. The results were expressed as the division index, which represents the average number of divisions for all cells or gated B cells in the culture.

First, the distributions of all the variables were examined using normal probability plots obtained using Shapiro-Wilk tests. All data had gaussian distribution, apart from the PBMC proliferation index stimulated with Con-A and PHA-M at day 77. To identify differences between groups (control vs. OmniGen-AF ${ }^{\circledR}$-supplemented; primiparous vs. multiparous cows), Student's ttest for unpaired data was used for data with gaussian distributions, and the Mann-Whitney test was used for nonparametric data. Statistical analysis was performed using graphPad Prism 7.0 software $^{\circledR}$ (GraphPad Software, Inc., San Diego, CA, USA). The results are reported as the mean \pm SEM. Significance was set at $\mathrm{P}<0.05$.

The immune system requires extensive lymphocyte proliferation, ensuring that antigenspecific $\mathrm{T}$ and $\mathrm{B}$ cells can expand with enough speed to effectively handle infection by pathogenic microorganisms and to enable vaccine-induced protective immunity. To the best of our knowledge, this is the first report that investigated lymphocyte proliferation induced by distinct mitogens in dairy cows supplemented with an immunomodulatory feed additive.

Despite the likelihood that innate and adaptive immunities share many effector mechanisms and the great evidence that supplementation of dairy cows with this commercial feed additive modulates the innate immune response (Wang et al., 2009; Nace et al., 2014; Brandão et al., 2016; Branson et al., 2016) and some aspects of adaptive immunity (Wang et al., 2009; Branson et al., 2016), our data did not support the hypothesis that supplementation with this feed additive robustly affects lymphocyte proliferation.

Overall, we only observed that dairy cows supplemented with this commercial feed additive during lactation showed an increase in spontaneous (unstimulated) PBMC proliferation $(\mathrm{P}=0.03$; Figure $1 \mathrm{~A})$ at 21 days after vaccination (day 77), and even worse, a lower B cell proliferation stimulated with $L$. heat-killed Leptospira borgpetersenii serovar hardjo $(\mathrm{P}=0.03$; Figure $1 \mathrm{~B})$ at 21 days after vaccination (day 77). Indeed, no significant difference was observed immediately before vaccination (day 56; data not shown). Furthermore, no alteration of leptospiral antibody titers determined by the leptospiral microscopic agglutination test was found in dairy cows that received this commercial feed additive compared with control cows (data not shown), which supports our lymphocyte proliferation findings. Furthermore, corroborating our data, a previous study showed that daily feeding dairy heifers with this commercial feed additive did not improve the antibody titers in animals vaccinated against Staphylococcus aureus mastitis (Nace et al., 2014).

Vaccination is an important tool to control infectious diseases, and it is somehow expected that immunostimulants often increase vaccine efficacy. However, our data did not show any solid evidence that this feed additive elicited a higher and sustained protective immune response due to vaccination. Nonetheless, as we used healthy mid lactating dairy cows, the possible beneficial effect of this additive on immunocompromised dairy cows, such as periparturient dairy cows, should not be discarded and requires further investigation. 

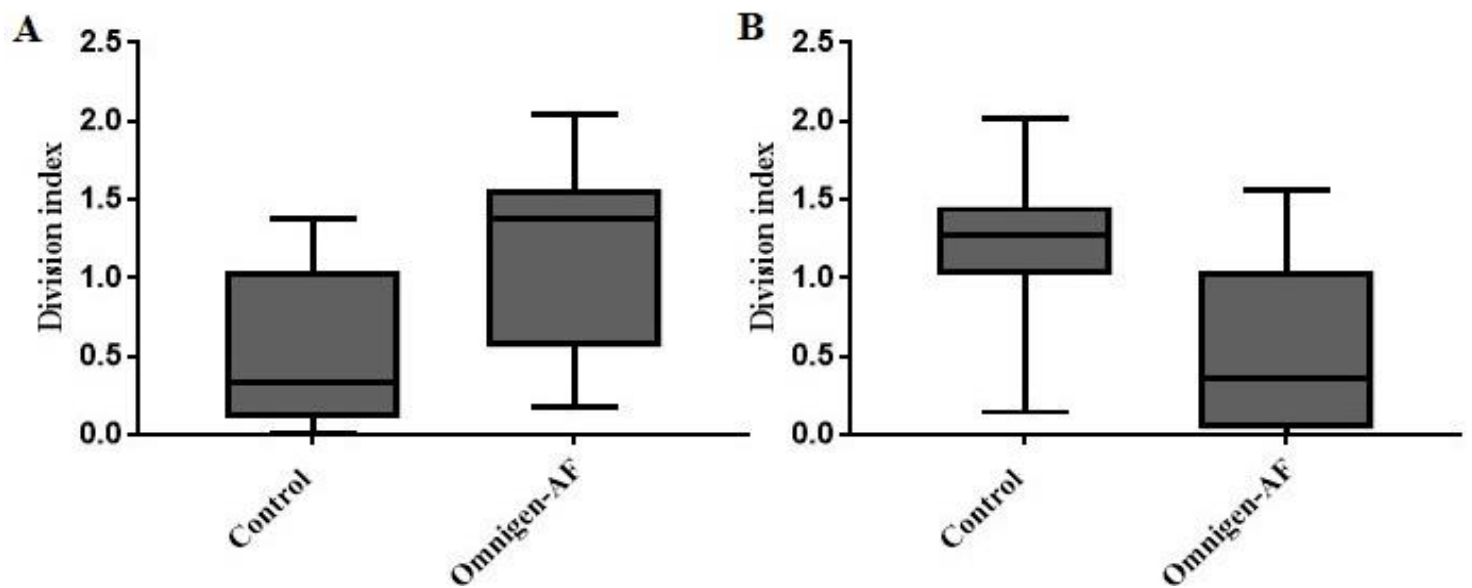

Figure 1. Lymphocyte proliferation determined by flow cytometry using 5-(6-) carboxyfluorescein diacetate succinimidyl ester labelled lymphocytes in dairy cows that received or not with $56 \mathrm{~g} / \mathrm{cow}$ daily asfed basis of OmniGen-AF ${ }^{\circledR}$. A) Higher spontaneous (e.g. unstimulated) proliferation by peripheral blood mononuclear cells isolated from dairy cows supplemented with OmniGen-AF ${ }^{\circledR}(\mathrm{P}=0.03)$ after 21 days of vaccination; B) Lower B cell proliferation stimulated with heat-killed Leptospira borgpetersenii serovar hardjo in dairy cows supplemented with OmniGen- $\mathrm{AF}^{\circledR}$ after 21 days of vaccination $(\mathrm{P}=0.03)$.

While the study size is limited, an intriguing finding of our study is that PBMCs stimulated with LPS behaved differently in primiparous and multiparous cows at 21 days after vaccination $(\mathrm{P}=0.03$; Figure 2); although there were no significant differences, PBMCs were always observed to be numerically higher in multiparous cows, both unstimulated and stimulated with ConA, PHA-M and Leptospira borgpetersenii serovar hardjo. To the best of our knowledge, apart from one study (Mehrzad and Zhao, 2008), no information is available on lymphocyte proliferation in primiparous and multiparous dairy cows. These previous authors also found that the lymphocyte proliferation induced by distinct mitogens was lower in primiparous cows, and they also suggested that this discrepancy may be a result of the presence of primed and activated lymphocytes from multiparous cows, as they have been much more exposed to antigens throughout their lives.

Keywords: OmniGen-AF, food supplementation, immunity, dairy cow

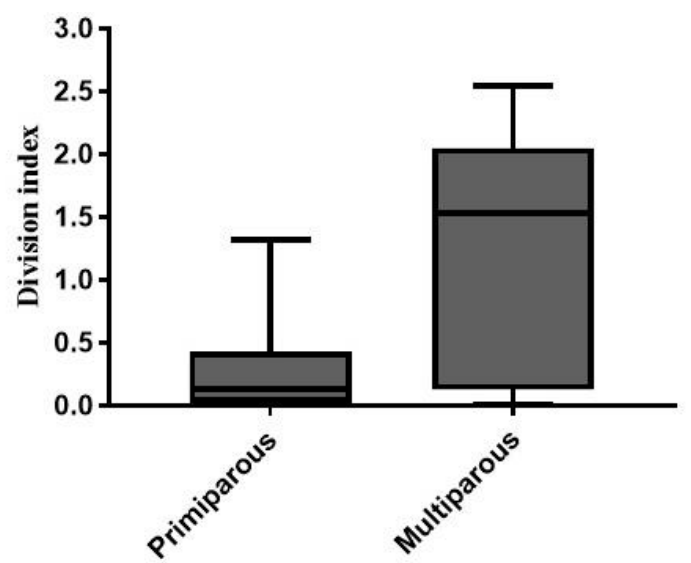

Figure 2. Higher lymphocyte proliferation of peripheral blood mononuclear cells stimulated with lipopolysaccharides (LPS) in multiparous cows after 21 days of vaccination. 


\section{RESUMO}

O presente estudo avaliou o efeito da suplementação com OmniGen-A $F^{\circledR}$ na proliferação de linfócitos e títulos de anticorpos após vacinação em bovinos leiteiros. Amostras de sangue periférico foram coletadas de 32 vacas leiteiras para quantificação dos títulos de anticorpos anti-Leptospira, e amostras de sangue periférico de 16 vacas leiteiras foram também coletadas para avaliação da proliferação de linfócitos. Observou-se que a suplementação com OmniGen-AF ${ }^{\circledR}$ aumentou a proliferação basal de linfócitos (sem estímulos) 21 dias após a vacinação $(P=0,03)$, apesar de reduzir a proliferação de linfócitos $B$ quando estimulada com Leptospira borgpetersenii serovar Hardjo inativada pelo calor $(P=0,03)$. Ademais, nenhum efeito da suplementação sobre a proliferação de linfócitos no momento imediatamente anterior à vacinação e nos títulos de anticorpos anti-Leptospira foi encontrado. Além disso, a proliferação de linfócitos estimulada com lipopolissacarídeos foi maior em vacas multíparas que em primíparas 21 dias após a vacinação $(P=0,03)$. Desse modo, o presente estudo demonstra que a suplementação com OmniGen$A F^{\circledR}$ não afetou de forma robusta a proliferação de linfócitos e os títulos de anticorpos anti-Leptospira após vacinação em vacas leiteiras sadias.

Palavras-chave: OmniGen-AF, suplementação alimentar, imunidade, vaca leiteira

\section{ACKNOWLEDGMENTS}

The authors are grateful for financial support from the Coordinator for the Improvement of Higher Education Personnel (CAPES). FNS is also grateful to São Paulo Research Foundation for his fellowship (FAPESP Project n. 2014/23189-4).

\section{REFERENCES}

BRANDÃO, A.P.; COOKE, R.F.; CORRÁ, F.N.; PICCOLO, M.B. et al. Physiologic health, and production responses of dairy cows supplemented with an immunomodulatory feed ingredient during the transition period. J. Dairy Sci., v.99, p.5562-5572, 2016.

BRANSON, J.A.; MCLEAN, D.J.; FORSBERG, N.E.; BOBE, G. Yeast-containing feed additive alters gene expression profiles associated with innate immunity in whole blood of a rodent model. Innate Immunol., v.22, p.249-256, 2016

COLE JR, J.R.; SULZER, C.R.; PURSELL, A.R. Improved microtechnique for the leptospiral microscopic agglutination test. Appl. Microbiol., v.25, p.976-980, 1973.

LEIVA, T.; COOKE, R.F.; BRANDÃO, A.P.; SCHUBACH, K.M. et al. Supplementing an immunomodulatory feed ingredient to modulate thermoregulation, physiology, and production responses in lactating dairy cows under heat stress conditions. J. Dairy Sci., v.100, p.4829-4838, 2017.
MEHRZAD, J.; ZHAO, X. T lymphocyte proliferative capacity and $\mathrm{CD} 4^{+} / \mathrm{CD}^{+}$ratio in primiparous and multiparous lactating cows. $J$. Dairy Res., v.75, p.457-465, 2008.

MURPHY, K.; WEAVER, C. Janeway's Immunobiology. 9.ed. New York: Garland Science/Taylor \& Francis, 2008. 924p.

NACE, E.L.; NICKERSON, S.C.; KAUTZ, F.M.; BREIDLING, S.; WOCHELE, D. Modulation of innate immune function and phenotype in bred dairy heifers during the periparturient period induced by feeding an immunostimulant for 60 days prior to delivery. Vet. Immunol. Immunopathol., v.161, p.240-250, 2014.

SODER, K.J.; HOLDEN, L.A. Lymphocyte proliferation response of lactating dairy cows fed varying concentrations of rumen-protected methionine. J. Dairy Sci., v.82, p.1935-1942, 1999.

SOUZA, F.N.; LATORRE, A.O.; CARNICEIRO, B.D.; SAKAI, M. et al. Apoptosis of $\mathrm{CD}^{+}$cells and lymphocyte proliferation in bovine leukemia virus-infected dairy cows. Arq. Bras. Med. Vet. Zootec., v.63, p.1124-1130, 2011.

WANG, Y.Q.; PUNTENNEY, S.B.; BURTON, J.L.; FORSBERG, N.E. Use of gene profiling to evaluate the effects of a feed additive on immune function in periparturient dairy cattle. J. Anim. Physiol. Anim. Nutr., v.93, p.66-75, 2009. 